\title{
食における言語資源に基づいたシズル感に関する因子情報の抽出
}

\author{
長谷川 永奈, 小宮 香乃, 齊藤 史哲, 石津 昌平 \\ 青山学院大学
}

\section{A Method of Factor Extraction of Sizzle Words Based on Language Resourses}

\author{
Ena HASEGAWA, Kano KOMIYA, Fumiaki SAITOH and Syohei ISHIZU
}

Aoyama Gakuin University, 5-10-1 Fuchinobe, Chuo-ku, Sagamihara-shi, Kanagawa 252-5258, Japan

\begin{abstract}
Sizzle" is a major factor in contemporary marketing because it evokes a feeling that indicates customer buying intention and appetite. In recent years, research on the expression of sizzle words has been actively conducted. In this study, we propose a support tool for understanding sizzle words through knowledge extraction by natural language processing. In onomatopoeia research that forms part of the sizzle word, factor analysis is generally used in subject experiments and analysis of questionnaire data. However, generally used factor analysis cannot be applied to language data because of the structure of the frequency matrix. In this study, we apply nonnegative matrix factorization to extract knowledge about sizzle words in review data from a recipe site. The quality of the learning results was improved by weighting the frequency matrix by BM 25 . Furthermore, we visualized acquired knowledge of sizzle words using a factor map and word cloud. Experimental results confirmed that keywords of factors influencing the sense of sizzle can be visually grasped.
\end{abstract}

Keywords : Sizzle Word, Text Mining, Non-negative Matrix Factorization (NMF), BM25

\section{1.はじめに}

シズル感とは顧客の購買意欲や食欲を高める感性的な要因 であり，消費者の五感を刺激する感覚を指す。これは焼いて いる肉や揚げ物がジュージューいう様子を表した“sizzle”を 語源としており，このルーツは古く，米国の経営コンサル夕 ントE. Wheelerによって1930年代に提唱された概念である. これは, 商品のデザインや広告, 製品コンセプトの策定といっ たマーケティングに関連する要因と深く結びついており, 近年ではその周辺の分野を中心に重要視され始めている. 食においては, 食品の味や香りのみならず, 調理・配膳時に おける音や見え方, 臨場感など様々な要因がシズル感に影響 を及ぼすと考えられており，パッケージや広告の制作，製品 開発に扔けるコンセプトの策定など様々なシーンに扔いて重 要性が高いといえる.

食における感覚的なニュアンスやシズル感は映像や音声の みならず，言語によっても表現されるものである。このよう な言語表現はシズルワード（または, シズル語）と呼ばれて 扔り，広告やパッケージ，Webに打けるクチコミはもとよ り，日常会話においても頻繁に利用されているものである。 例えば,「コトコト」は弱い火力で鍋の中の物が煮える音や 様子を想像することができるし，「ホクホク」はあたたかく， やわらかい芋などの料理を連想できる。このようにシズル ワードを利用することによって，食品の魅力や消費者が求め る情報を端的に伝えることが可能になる．

その一方で，そのニュアンスは把握できるが，明確な意味 の把握や解釈・定義が難しいケースも多々見受けられる. 特に,「コク」や「キレ」「梁み」などについては定義や意味
合いについて広く議論がなされており，味覚に関連する研究 を中心として様々な研究がなされている。 さらに, シズル ワードにおいては「アッサリ」「ピリピリ」「モチモチ」など のオノマトペが多く含まれていることから，オノマトペの 感性的な性質に目を向けた研究も関連研究として捉えること ができる。オノマトぺに関連した先行研究には被験者を募っ た実験やアンケート調査などに基づいて収集されたデー夕を 解析することで，シズルワードまたはオノマトぺに関する 知見の獲得を目指すものが多い。ここでは，類似した特徵量 を統合的に扱うことで背後に隠れたデー夕に影響を及ぼす 要因を抽出できることから，因子分析などの感性的・心理的 な要因を抽出する解析方法が一般的に利用されている.

さらに, シズルワードに関する言語資源の解析, すなわち, 自然言語処理やテキストマイニングに基づいた研究に目を 向けると, Web上のデータに拈いて対象単語と共起した キーワードとの対応関係を調査する分析手法が中心であった。 その一方で，言語コミュニケーションを通じたこれらの特性 については，言語デー夕を素性とすると大規模疎行列となる ことから,一般的な統計的分析手法の直接的な適用が難しい. このため, 被験者実験における要因抽出において中心的に用 いられてきた因子分析などの分析手法は, 充分に適用はされ てはこなかった

以上の背景より, 文書データの解析において, シズルワード における潜在的な特徵を表す要因を抽出できれば, シズルワー ドの特徵や性質の理解支援への貢献が期待できる。 そこで 本研究では, 近年様々なデー夕において広く利用されている, 非負值行列因子分解 (Non-negative Matrix Factorization, NMF）をシズルワードの用例データに対して適用すること で，言語資源からのシズルワードの特性に関する要因抽出を 
試みる。これによって, 実験結果からシズルワードに関する 要因の抽出㧍よびクラスタリングを実施した。 ここでは, 素性抽出に扮ける単語の重み付けとして情報検索尺度を適用 することで, 分析結果の質の向上をはかった，さらに，この 結果に対して解釈を与えるための方法としてNMFの学習 結果の可視化を試みることで知見獲得のためのデータの理解 支援を新たに試みた。

以下，本論文では 2 章ではシズルワードに関する基礎事項 および関連研究についてまとめ, 3章にて本研究において 利用する手法について整理する４章では本研究における 分析方法について述べる．5章は実データに基づいた分析の 結果について述べる，6章は考察，7章は結論である。

\section{2. 分析対象としてのシズルワード}

ここでは，解析対象であるシズルワードの概要および，そ の関連研究について概説する。

\section{1 シズルワードの分類}

先述の例のように, シズルワードにはオノマトペ（擬音語· 擬態語）が利用されることが多いが，他にも「クリーミー」の ように食品の味覚に対応するものや「歯ごたえのある」など の触覚に関するもの,「新鮮」や「産地直送」といった商品 に関する情報を直接的に表現するものもこれに含まれる。 大橋ら [1]によると, これらは上記の順に「味覚系」「食感 系」「情報系」の3 種類に大別できるとのことである.

味覚系のシズルワードとは，味覚および臭覚に対応したも ので，評価対象に対する味を表している，臭覚も味の判断に 強く影響を及ぼすことから, 大橋らの類別化では臭覚も味覚 系のシズルワードの対象として含まれている。たとえば, 「コク」や「深み」,「マイルド」などの曖昧さを含む表現や, 「甘い」や「辛い」,「酸味」などの味覚を直接的に表現する 方法，「余韻のある」や「飽きのこない」，「複雑な」などの 人間の気分や印象・感情に対応する表現も味覚系のシズル ワードに含まれる。

次に，食感系のシズルワードについて述べる。これは, 触覚および聴覚に訴えかける表現である。食感を表す際には 舌触りや歯触りを音に見立てて表現することが多いことか ら，触感系には聴覚の影響も含まれる。また，ここでは調理 や配膳時に発せられる音などもこの部類に入る。「サクサク」 「プリプリ」などの歯触りに関するものや「ザラザラ」「つる つる」などの舌触りに関するものが代表的な食感系シズル ワードとして挙げられる。 また,「あつあつ」「冷え冷え」など といった対象の温度を表すものや，「硬い」「ふんわり」など 硬度を表すものなどもこれに含まれる。なお，オノマトペに 対応するシズルワードは食感系に分類されることが多い，

最後に，情報系のシズルワードとは，対象の食品に関する 情報を表現し，人が持つ知識や知恵に基づいた価值観などに 訴えかける，たとえば，「ノンオイル」「減塩」「無農薬」な どの表現は健康を意識する際に重要な情報となり得るし,
表1 味覚系のシズルワードの例

\begin{tabular}{|c|c|c|}
\hline 飽きのこない & コクがある & ピリッと \\
\hline 味わい深い & こってり & 深みのある \\
\hline あっさり & さっぱり & ほんのりした \\
\hline 甘い & さわやかな & マイルド \\
\hline 甘辛い & 渋い & まったり \\
\hline 甘さ控えめ & デリシャス & まろやかな \\
\hline 薄味 & 濃厚な & 余韻のある \\
\hline
\end{tabular}

表2 食感系のシズルワードの例

\begin{tabular}{|c|c|c|}
\hline あたたか & さっくり & 弾力がある \\
\hline あつあつ & ざっくり & つるん \\
\hline 硬い & ザラザラ & ドロドロ \\
\hline 噛み心地のよい & しこしこ & ねばねば \\
\hline 口当たりがよい & しっとり & ぷにぷに \\
\hline ゴクゴク & ジューシー & ムチムチ \\
\hline コシのある & 新食感 & もっちり \\
\hline
\end{tabular}

表3＼cjkstart情報系のシズルワードの例

\begin{tabular}{|c|c|c|}
\hline 揚げたて & 具だくさん & 手作りの \\
\hline 朝採り & 旬 & 懐かしい \\
\hline オーガニック & 滅塩 & ヘルシー \\
\hline おしゃれな & 高級感 & プレミアム \\
\hline がっつり & こだわりの & 秘伝の \\
\hline カロリーオフ & 産地直送 & 上品な \\
\hline 完熟の & 自家製の & 贅沢な \\
\hline
\end{tabular}

「揚げたて」「産地直送」「新鮮」などは対象食品の鮮度に 関する情報を補う。「素朴な」「上品な」などは先述の食感系 や味覚系では表現しきれなかった, 顧客の嗜好や価值観に 訴えかける食品の評価軸を提供すると思われる。このように, シズルワードは言語を通じて感性的な感覚に対応している.

以下本論文中にて扱うシズルワードは，これに倣って， この類別化に基づいたものを分析対象として扱うことに する，なお，文献 [1]に揭載されているシズルワードの一例 を表1一表3に示す.

\section{2 関連研究と本研究の位置付け}

シズルワードは感性的な表現を多分に含むことから, 近年 では様々な分野において研究対象として扱われている。ここ では, 本研究との関連性が高いと思われる先行研究を整理し, 本研究との差異および共通性についてまとめる，先に述べた とおり, シズルワードに関する調査および研究は, 被験者を 募った実験やアンケートに基づいた知見の獲得を目指すもの と，シズルワードに関する用例，すなわち文書デー夕に基づ いた研究に類別できることから，これらについて詳述する.

アンケートなどの調査に基づいた知見の獲得として最も代 表的なものとして, 大橋ら [1]による, 大規模な調査が挙 げられる。ここでは，シズルワードについて分析しており， その性質や使用傾向について, 詳細に分析がなされている. 
また, 被験者を募った実験においては, 石橋ら［2］は米菓 を対象としてシズルワードの印象評価に関する研究などが 挙げられる，シズル感を伝える際に，しばしばオノマトペが 利用されることから，オノマトぺに焦点を当てて解析を行っ ている。ここでは，オノマトぺの印象などの心的な性質を 抽出することを目的としていることから，因子分析などの 要因を抽出する分析手法が採用されている.

シズルワードに限らず，オノマトペなどの感性的な表現に 関する類似した研究に目を向けても, 同様なアプローチが取 られている。 これらの研究では，対象のオノマトペに関する 共通要因の性質に関する議論やそれらの類似性に関する議論 がなされている。たとえば, 高橋ら［3］はオノマトぺの対人 接触行動との関連性について分析を試みている，矢口 [4] は異なる感覚に属する語を組み合わせた表現である共感覚的 表現においてオノマトぺの意味構造について解析を行ってい る。山本ら [5] は視覚に関するオノマトペとデザイン経験 の関連性が評価構造に及ぼす影響について研究を行った。 これらいずれの研究においても, 取得されたデータセットに 対する因子分析に基づいた解析がなされている.

また，言語資源に基づいたシズルワードに関する研究とし ては, Twitterに代表されるマイクロブログやレシピサイト上 の言語デー夕などを対象とした研究が主流である。ここで は，シズルワードと共起する食品に関する単語間の関連性な どに基づいた分析やアプリケーションの開発が行われてい る. 代表的なものとしては, 加藤ら [6]の食品検索手法の 研究があげられる。ここでは, 検索対象の食品とシズルワー ドに基づいてユーザのシズル感に一致した食品検索を支援す るツールを，単語間の共起頻度を指標とすることによって実 現している。 また, ラートサムルアイパンら [7] は（シズル ワードに含まれる) オノマトペを利用して料理の推薦システ ムを構築している。ここでは, TF-IDFを用いて, 推薦対象 を評価している，青木ら［8］はオノマトぺに基づいて食に おけるレビュー評価に影響する単語を抽出し, 顧客満足度に 関する決定木を構築した。これらのシズルワードの言語資源 に基づいたアプローチではいずれも, 単語間の関連性などに 基づいて算出される指標やルールマイニングに基づいた手法 であり，これまでに多くの感性的要因の抽出において利用さ れてきた因子分析などに基づいた知見獲得を目指すものでは ない。 これは一般に, 言語資源を多次元データとして扱う際 は素性 (特徵量)に単語の出現頻度が用いられることから, 対象デー夕は大規模疎行列となり, これらの適用が難しいこ とに起因する。 データの構造上, シズルワードやオノマトペ に関する意味的な構造の解析に利用されてきた因子分析など の手法を言語データに直接適用することは難しい

そこで本研究では，言語資源に基づいたシズルワードに 関する因子空間を構築する手法として非負值行列因子分解を 採用する. 非負值行列因子分解は, デー夕数に対して次元が 大きい大規模疎行列の解析においても, 有効に機能し, 因子 分析と同様な結果が得られることから, シズルワードの言語 資源の解析においても有効活用が期待できる.

\section{3. 分 析手法}

ここでは, 本研究に抏いて重要となる分析手法について 整理する。

\section{1 非負值行列因子分解}

本研究では, レシピサイト上のコメント文を対象として シズルワードと共起した文書の分析を行う。先述のとおり, 一般に文書データは高次元かつ 0 頻度の要素を多く持つ大規 模疎行列になる。分析には，このような文書デー夕において 文書間の共通要因を自動抽出できる手法を利用し，シズル ワードにおける利用傾向に関する分析を行った．分析ツール としては, 近年の自然言語処理分野において因子（トピック） の抽出に执いて高い性能が示されている非負值行列因子分解 (Non-negative Matrix Factorization, NMF） [9,10］を利用し, それらの手法から抽出された因子について解釈を与えた。

$\mathrm{NMF}$ は解析対象のデー夕行列を, 複数の基底を用いる ことによって二つの行列の積に近似するデータ解析手法で, 因子としてデータの次元縮約を行いつつソフトクラスタリン グを実現する。データの行列 $X$ をインスタンスと基底の行列 と基底と変数の行列の積に基づいて， $X \cong U V$ となるように, フロベニウスノルム $\|X-U V\|_{F}$ を最小化する. データ行列の 成分が非負であるという制約を設けることで，軸が直交する ことを回避している。

なお，NMFの学習則は以下に示す通りである.

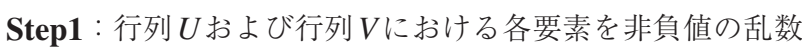
によって初期化する。

Step2：あらかじめ指定した更新回数を満たすまで，下記の 更新式を計算する。

$$
\begin{aligned}
& \bar{u}_{i k} \leftarrow u_{i k} \frac{(X V)_{i k}}{\left(U V V^{t}\right)_{i k}} \\
& \bar{v}_{k j} \leftarrow v_{k j} \frac{\left(U^{t} X\right)_{k j}}{\left(U^{t} U V\right)_{k j}}
\end{aligned}
$$

ここでは, $X$ はデータの行列を表しており，UおよびVはそれ

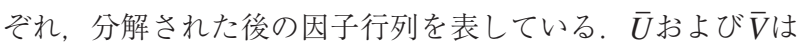
それらの更新後の因子行列である。 $k$ は基底数，すなわち あらかじめ指定した因子の数を表している。 $i, j$ はそれぞれ 単語とインスタンスに対応するインデクスである.

これは文書データや顧客行動データなどの大規模疎データか らの因子抽出において機能していることから, 本研究にて想 定しているデータにおいても期待できる $[11,12]$.

\subsection{BM25}

文書データの解析において単語の出現頻度を素性として扱 う際に，TF-IDFなどの検索尺度に基づいた単語の重み付け がなされる. TF-IDFの計算方法には様々なものがあるが, 次式によるものが広く利用されている。 


$$
\begin{aligned}
& \operatorname{TFIDF}\left(D, q_{i}\right)=\operatorname{TF}\left(D, q_{i}\right) \times \operatorname{IDF}\left(q_{i}\right) \\
& \operatorname{IDF}\left(q_{i}\right)=\log \frac{N}{d f\left(q_{i}\right)}+1
\end{aligned}
$$

ここでは, $T F\left(D, q_{i}\right)$ は文書 $D$ における $i$ 番目の単語 $q_{i}$ の出現 頻度を表している. $d f\left(q_{i}\right)$ は墦目の単語 $q_{i}$ を含む文書数を, $N$ は全文書数を表している。TF-IDFでは対象単語が含まれ ている文書数が少なく，かつ，同一文書中にて多く利用さ れている単語を高く評価する。すなわち、これは頻繁に 利用される, ありきたりな単語には低く, 利用対象が限定 的で特徵的な単語には高い值を割りあてることを意味して いる.

一般に，(4) 式の TF-IDFはTFの值に比例して大きくなる ことから, 文書長の影響を受ける性質がある [13]. 長い文 書は対象の単語を多く含む傾向にあるため, TF-IDFの值も 文書長が長くなるにつれて大きくなる。この様な性質を回避 するためにBM25［14］などが提案されている.BM25とは, 情報検索や特徵的な単語の重み付けの指標であり, 文書デー 夕からの情報抽出において近年利用され始めている [15]. ここでは，BM25においてはTF-IDFでは考慮されていな かった文書長などが単語出現頻度に及ぼす影響が考慮され ている.このため, 分析対象において長い文書に埋もれて しまった，真に特徴的である単語の抽出が期待できる。 そこで本研究では, 特徵的な単語を抽出するッールとして BM25を採用する。

文書 $D$ 中における $i$ 番目の単語 $q_{i}$ に対する BM25の值は 次式によって求められる.

$$
B M 25\left(D, q_{i}\right)=\operatorname{IDF}\left(q_{i}\right)\left\{\frac{T F\left(q_{i}, D\right)\left(k_{1}+1\right)}{T F\left(q_{i}, D\right)+k_{1}\left(1-b+b \frac{|D|}{a v g d l}\right)}\right\}
$$

ここでは, $T F\left(q_{i}, D\right)$ は文書集合 $D$ 中の $i$ 番目の単語 $q_{i}$ に対す る TF值を, $|D|$ は文書 $D$ の長さ (全単語数) を, $a v g d l$ は全文書 の平均文書長を表している. $k_{1}\left(1<k_{1}<2\right)$ および $b(0<b<1)$ はそれぞれ単語出現頻度と文書長の影響の大きさを調整する パラメー夕である。なお，式 (5)に扔ける右辺第一因数は 単語 $q_{i}$ に対するIDFであり, BM25の計算においては次式の ように定義されている.

$$
\operatorname{IDF}\left(q_{i}\right)=\log \frac{N-d f\left(q_{i}\right)+0.5}{d f\left(q_{i}\right)+0.5}
$$

これは, 式 (4) と同様に特徵的な単語を高く評価し，ありき たりな単語の評価を低くするように機能する。一般的には, IDFは式 (4)のような定義式に基づいて計算されることが 多く，值域はこれとは異なるものになる，基本的な考え方と しては，全文書中に打いて利用される割合が低い単語ほど 大きくなる性質があることはいずれにおいても同様である が, 式 (4) は非負であるのに対して, 式 (6) は負の值もとり うる点において異なる。

\section{NMFに基づいたシズルワードの分析}

ここでは，新たなシズルワードの分析を試みるにあたり， その分析方法について詳説する。

\section{1 分析における指針}

本研究では, レシピサイトにおける言語資源を対象として シズルワードに関する知識抽出を試みる。分析においては, 各シズルワードを含むコメント内において出現した単語の 頻度行列を用いる。ここでは，インスタンスはシズルワード であり，素性は各シズルワードを含む全コメント内で利用さ れた単語の出現頻度である。すなわち，各シズルワードを含 むコメント内で出現した単語の頻度を全てマージすることで 構築した文書行列が対象デー夕となる。このようなデー夕を 分析することで，シズルワードと共起する単語に関する性質 およびシズルワード間の類似性について議論が可能になり, シズルワードに関する知識抽出が期待できる.

その一方で，このようなデー夕を扱う際に，シズルワード 自体の利用頻度の差異が知識抽出において障害となる。これ は，頻繁に利用されるシズルワードは関連する単語の頻度も それに伴って大きくなるが, 利用頻度が小さいシズルワード は逆に関連単語の頻度も小さくなることに起因する。本研究 では，単語に関する因子の抽出を目的としており，出現頻度 を共起単語がシズルワードに及ぼす影響度とみなすことで 分析を実施することから, 単語の出現頻度を直接的に扱うと 得られた知識の質の低下を招く。先述のとおり, このような 状況下では TFや TF-IDFの適用は不具合を招く可能性が高 く, BM25のような単語の重み付けが有効であるといえる.

以上より, 本研究ではBM25による重み付けを行うことに よって, 共起単語のシズルワードへの影響度を補正すること で, 分析の質の改善を試みる. なお㇒, 一般的なBM25に扔ける IDFは式 (6)によって算出されるものであり, 負の值も取り 得ることから非負值の制約を設けている NMFへの適用を妨 げるものである。そこで, 本研究では, BM25におけるIDF の計算を一般的な TF-IDFにおいて用いられるIDF (式 (4)) を利用することでBM25が負值になることを回避する.

\subsection{NMFによる解析結果の可視化}

NMFを用いてデー夕解析を行う際は, 何らかの形で学習 結果に対して解釈をあたえる必要がある。一般的には, 得ら れた素性に対する重みの大小に基づいて因子の内容について 解釈を与える。本研究では, 学習結果に扔ける因子に対して 影響の強い共起単語やシズルワードを視覚的に把握するため に，ワードクラウドをもちいて各因子の内容を可視化する. 影響の大きい単語ほどその中心に大きく表示されるため, これによって視覚的に学習結果の把握ができるようになる.

また, データの全体像として獲得された複数の因子の関連 性や類似性を把握する必要がある。これを行うために, 因子 間のネットワークを2次元平面上に配置することによって, 学習結果を可視化する. 


\section{3 提案法における処理手続き}

ここでは，本研究における分析の処理手続きの全体像拈よ び各ステップの内容について説明する，本研究にて提案する 分析の処理手続きによってデー夕を分析することで，シズル 感に関する因子情報を言語データから抽出することができ る. 分析の処理手順は以下のとおりである。

Step1：対象のシズルワードを含むレビュー文を抽出し， シズルワードごとに文書集合をマージする.

Step2：シズルワードをインスタンスとし, 出現単語を素性 とした頻度行列を作成する

Step3：頻度行列に対して単語の重み付けを行う.

Step4：Step3の行列に対してNMFを学習する.

Step5：NMFの学習結果を可視化する.

Step1 およびStep2の結果は，分析において利用するデー 夕の作成を表している。 上記のStep1はあらかじめ用意した リスト内のシズルワードを含むレビューを抽出し，シズル ワードごとにマージし，シズルワードの個数だけドキュメン トデータを作成する，Step2では，Step1で作成されたデー タセットに対して形態素解析を適用することで, 品詞ごとに 分かち書きし, 単語の出現頻度を求めている.

Step3 およびStep4の結果は, 分析手法による知識抽出の 手続きであり，前に述べた分析手法を適用するフェーズであ る. Step3はBM25による単語の重み付けに対応しており, 単語の出現頻度の行列を共起単語に対する BM25行列を構 築する. Step4はNMFの学習ステップである。式 (1) (2)に よってStep3で獲得された重み行列をシズルワードと因子の 行列と, 因子と共起単語の行列に分解する。本研究で行う シズル語の分析の概略は図 1 に示す通りである. 左辺の頻度 行列がシズル語とそれに対して共起した単語の頻度である。

Step5は得られた結果を視覚的に理解できるようにするた めに，学習結果の可視化を行う。ここでは，NMFによって 分解された共起単語の行列㧍よびシズルワードの行列におけ る重みをそれぞれの因子ごとに抽出し, ワードクラウドを適 用することによって, 反応の大きさに応じた可視化を行う. ここでは, 図1の右辺に打ける左側の因子行列の列べクトル および右側の因子行列の行ベクトルがそれぞれの因子に対す る重みを表している。これより，それぞれに対して内容を

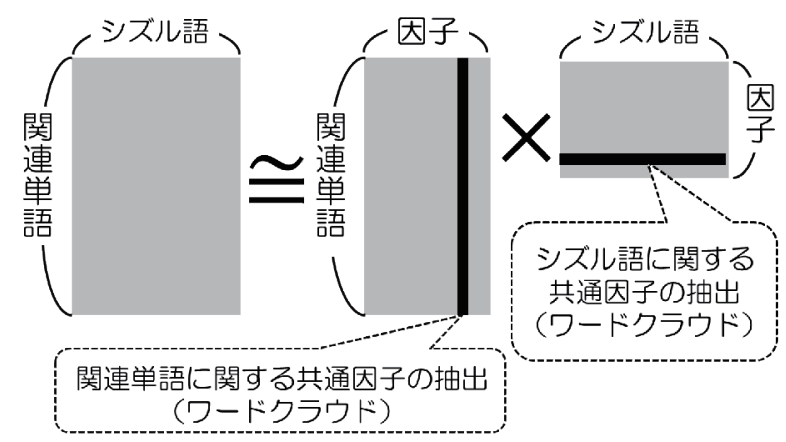

図1 本研究における分析の概要
ワードクラウドとして表示することで各因子に対するキー ワードそれぞれの影響度を可視化することができる.

また，因子間の重みのコサイン類似度を計算し，因子の 類似度グラフ (ネットワーク) を構築し, 二次元平面上に表 示する。コサイン類似度が一定の值を超えたものをリンク で繋ぐことで，因子間の類似性を視覚的に把握できるよう にした。

\section{5. 提案法によるシズルワードの分析}

\section{1 分析に用いたデータ}

本研究では，シズルワードが含まれている可能性が高いこ とを理由として，レシピサイトにおけるレシピに関するコメ ント文を解析対象とした。データは楽天株式会社より提供さ れた，楽天レシピに拈けるデータである[注1．ここでは， サイト上に公開されたレシピに対して，ユーザからの レビューとして，「つくったよレポート(つくレポ)」が提供 されている. 対象レシピ内で利用されたつくレポおよび, それに対してレシピ提供者からの返事を解析対象とし，その 中でも解析対象であるシズルワードを含むものを取り出して 解析を行った。

本研究にて対象としたシズルワードは, 文献 [1]におけ るリストに掲載されているものを用いた。ここでは，ひらが な表記もしくはカタカナ表記の何れかが掲載されていたが, 本論文中では, 両方の表記を採用しており，ひらがなはカ夕 カナに, カタカナはひらがなに変換を施したものも元のシズ ルワードリストに追加している。なお，これらの出現頻度を 求める際は, 形態素解析器 $\mathrm{MeCab}$ 利用している。ここで は, カタカナ表記された単語およびひらがな表記された単語 は別の単語として認識され, それぞれに対して出現頻度が算 出されている. 抽出された単語の中には, 顔文字や数字など の単語以外の文字列，挨拶などの表現，食との関わりの低い と思われる単語, 固有名詞などが多く含まれていた [注2]. これらは, 解析に拈りつイズとなるばかりでなく, 結果 の解橎においても悪影響を及ぼすと考えられるため, あら かじめ人手によって削除した行列を解析対象とした。また， データセット内で利用された回数が 5 回未満のシズルワード は，分析におけるノイズになることから分析対象から除外 した。

\section{2 分析ツールの設定}

形態素解析において利用した品詞は名詞と形容詞を用い, さらに, 総出現頻度の最小值は 100 とした. NMFにおける 基底数すなわち, トピックとして扱う因子数は 20 個, NMF の学習に扔ける更新回数は 100 とした。 BM25に扔けるパラ メータ $k_{1}$ および $b$ の設定は, 文献 [14] 等において一般的な 值として推奨されている $k_{1}=1.2, b=0.75$ を採用した。因子 間の関連性を表示するネットワークは因子間の荷重のコサイ ン類似度に基づいており, 閾值 0.2 を超えた因子間にアーク を構築した。 


\section{3 分析結果}

分析結果として, 学習の結果より獲得された情報につい て説明する。まず, NMFの学習結果から獲得された因子の 類似度グラフは図 2 , 図 3 に示すとおりである. 図 2 はシズ ル語の因子行列に基づいた類似グラフであり, 図 3 は出現 した関連単語の因子行列に基づいた類似グラフである。 NMFは因子としてデータの特徵量を抽出しているため, それぞれの因子の類似度は低くなる。図 2 および図 3 では, 因子間における類似度の值があらかじめ指定した閾值を 超えた場合のみ, アークで繋いでいる。ここでは, 何らかの アークを持つ因子を表すノードを明るい色（図1ではピンク 図2では水色)で示している。逆に類似した因子を持たない 因子のノードを濃い色（図1では深緑, 図2では紺色)で示 している.

図4および図 5 はMFの学習によって獲得された関連 単語に関する因子行列とシズルワードに関する因子行列の 内容を可視化した結果を表している. 図4では, 関連単語に 対する重みを因子ごとの荷重ベクトルに対して, 図5では, シズルワードに対する重みを因子ごとの荷重べクトルに対し てワードクラウドを構築することで, それぞれの内容を視認 可能にしている.

13 (11)

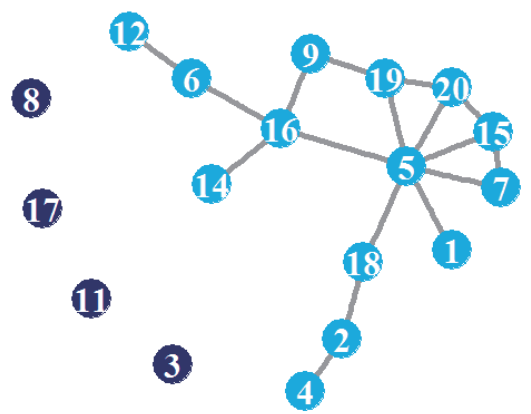

図2

シズルワードの因子における類似度グラフ

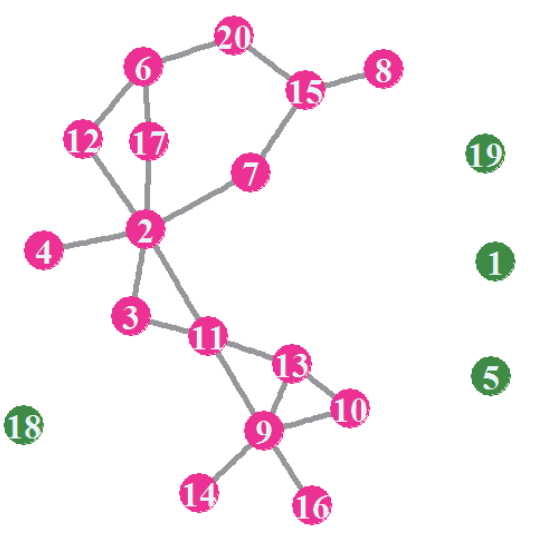

図3 関連単語の因子における類似度グラフ
ここでは, 6個の因子（第2因子，第 5 因子，第6因子， 第 8 因子, 第9因子, 第15因子) を選択し，それらを表示して いる。 これは図2, 図3のネットワークからリンクが多いも のや，内容について議論しやすいと思われたものを選んだ. さらに，手法としての性能やその限界について議論するため に, 図6, 図7では, 逆にネットワーク内に拈いてリンク数 が少なく, 独立性の高いものや内容の解釈が難しいものを 選び，ワードクラウドによって上と同様な可視化を行った。 なお，図示した因子は第 1 因子と第14因子である。

\section{4 結果の解釈と考察}

それぞれの因子が持つ重みベクトルの内容 (ワードクラウド) に注目し，各因子に解釈を与える。まず，第2因子に着目する と, 関連単語は「トースト」や「玉子」,「ベーコン」,「食パン」 などが含まれており，パンによる朝食を連想させる単語が多 く,「あっさり」というシズルワードと朝食に求められる感覚 の説明がつく，さらに，「もち」，「招にぎり」，「焦げ目」な どの単語も併せて考えると,「カラッ」や「からっ」「からり」 「カリカリ」なども焼き物の調理と感覚が一致する。

第 5 因子の関連単語の内容においては, 一見すると単語 の共通性が無いように見える。しかし，ここには「女」や 「女の子」,「バレンタイン」などの女子を対象としたキー ワードが含まれており，それに基づいて内容を確認すると， 果物や材料に打いて甘いものが多く踏まれており，女性の ニーズが高いといえるレシピに関連する表現が含まれてい る因子であると考えられる。ささらに、シズルワードの方に 注目すると「おしゃれな」の影響が強く，おしゃれな甘味 のレシピの受けが良いと考えられる。

第6因子には，「京都」や「大阪」といった関西の地名を 表すキーワードが含まれている。 また食材の内容について 確認すると,「汁」や「スープ」,「ダシ」などの汁物を連想 する単語が含まれている。これらに対して最も強く反応した シズルワードが「おしゃれな」であり, 関西方面の味付けや 汁物に対する調理方法に「おしゃれな」印象をあたえる傾向 があると読み取れる。また,「アッサリ」「あっさり」が共に 中程度の反応を示しており, 関西方面の味付けにおける印象 を的確に対応付けられている.

第9因子の関連単語のワードクラウドに着目すると, 「コーヒー」や「牛乳」,「マーガリン」,「ヨーグルトなど」の 食材の他に「オレンジ」,「ブルーベリー」,「アップル」など 果物や「目覚め」などの単語が含まれており, 洋風の朝食を 連想させる因子であると読み取れる。この文脈でシズルワー ドの因子に着目すると,「あたたか」や「カリカリ」といっ た要因の影響が大きく, 洋風の朝食は「扎しゃれ」な印象を 与えていると読み取れる。

第 8 因子の各ワードクラウドに着目すると,「わさび」や 「柚子」,「しょうが」,「みょうが」,「ごま」などの薬味や 調味料に関連する食材の関連単語が含まれており, これらが 「あっさり」や「あたたか」などのシズルワードに影響を 及ぼしていると考えられる。他に「弁当」や「定番」などの 

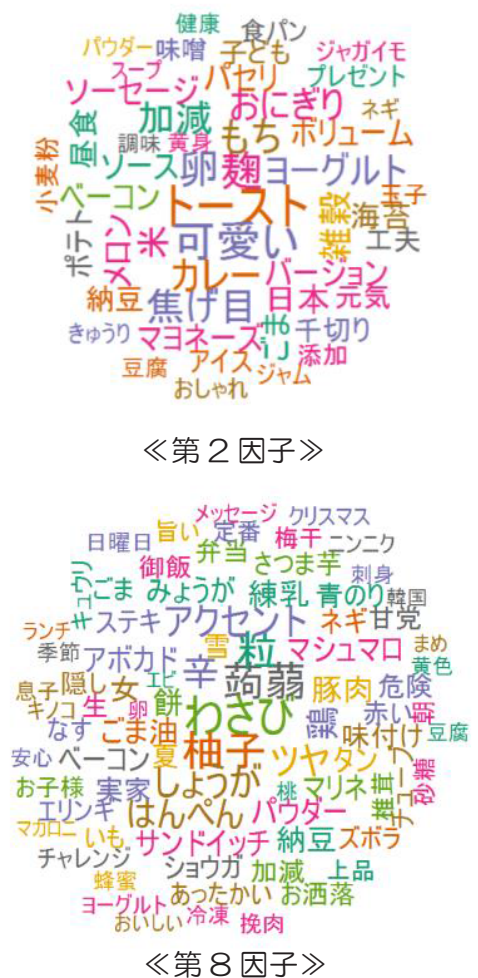
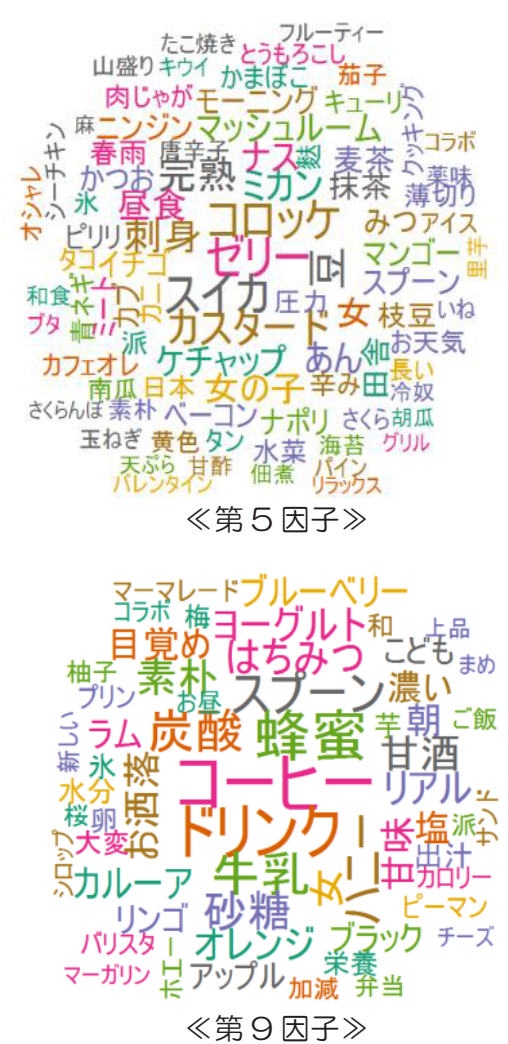
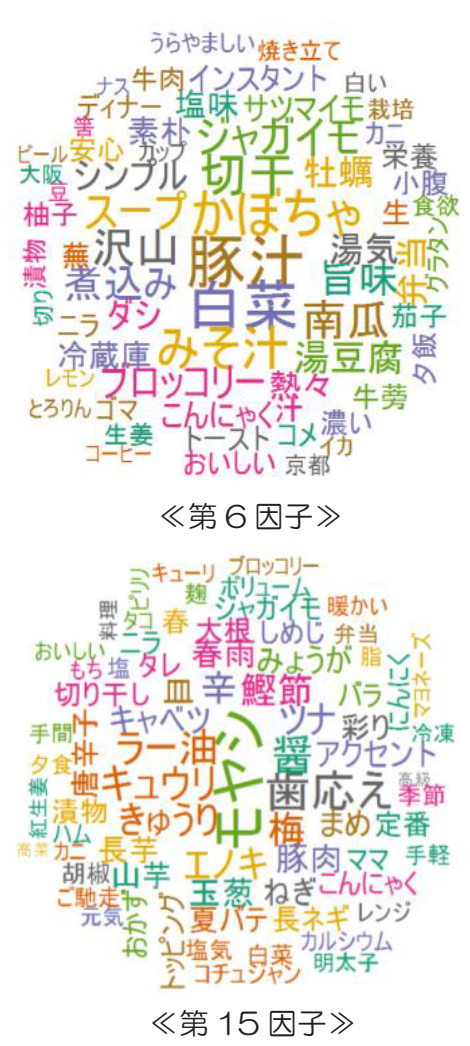

図4NMFにおける因子と関連単語の関係 (トピック)

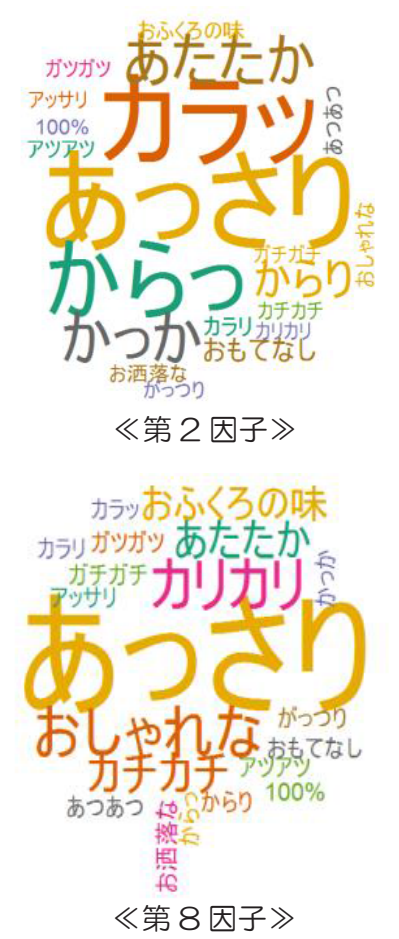

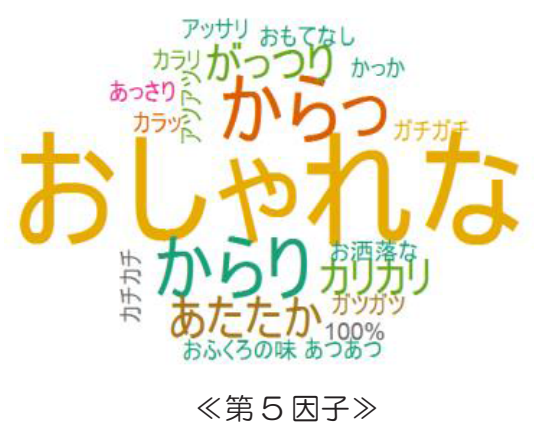

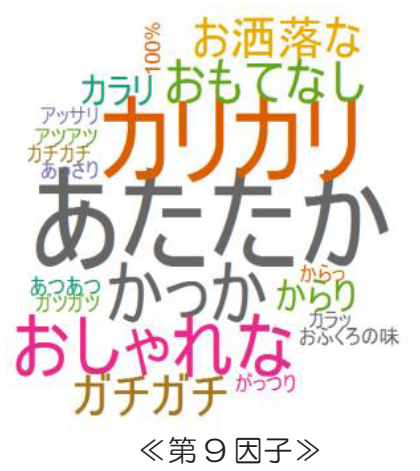

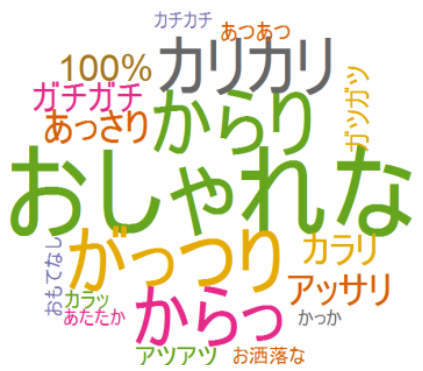

《第 6 因子》

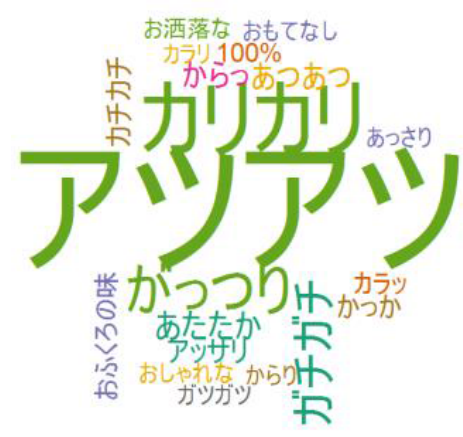

《第15因子》

図5 NMFにおける因子とシズルワードの関係 (トピック)

\footnotetext{
キーワードが関連単語内に含まれており，これらは「おふく

ろの味」などに影響していると考えられることから，あっさ りした家庭料理 (おふくろの味) を求める際に和風の薬味な どが有効活用できると推察できる.
}

第 15 因子に着目すると,「唐辛子」,「ラー油」,「奨」, 「ニンニク」,「コチュジャン」などの中華料理などに代表さ れる東アジアにおける辛味をべースとした料理を対象にして いる因子である可能性が高い.これらは, 暖かい料理が多く, 


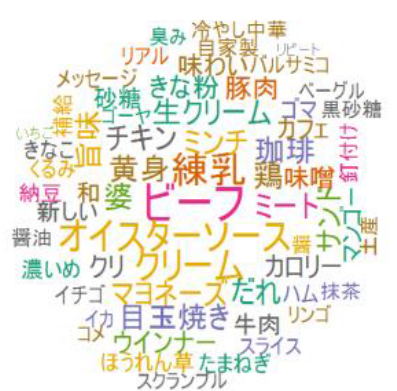

《第 1 因子》

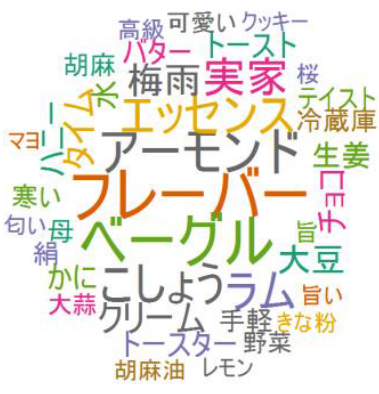

《第 14 因子》

\section{図6 独立性の強い因子における関連単語の関係}

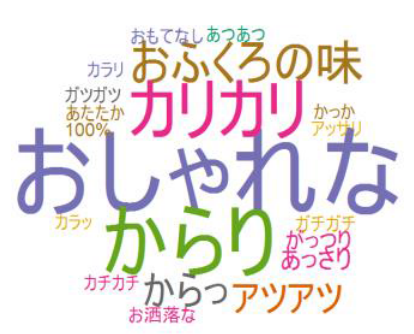

《第1 因子》

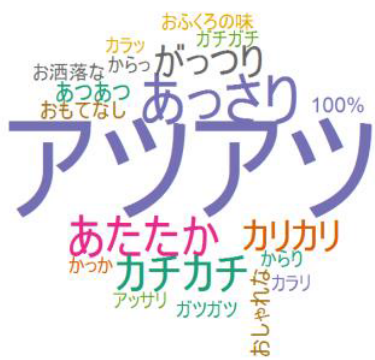

《第 14 因子》
図7 独立性の強い因子におけるシズルワードの関係

体温やスタミナを高める料理ととらえられることが多いこと から，この印象が「アッアツ」や「あたたか」を連想させた と考えられる.ささらに，これらの料理は家庭など一般に調理 される際は，おなかいっぱいに勢いよく食す際によく用いら れる「がっつり」が反応したと考えられる.

図6, 図7の他に類似している因子が少ない者に目を向ける と, 第 1 因子において出現した単語の内容の解釈は難しい. 共通性の高い単語として「ミンチ」「チキン」「豚肉」「ビーフ」 などの肉料理を連想させる一方で,「練乳」や「生クリーム」 「黒砂糖」「リンゴ」「マンゴー」のようなデザートを連想させる キーワードが混在しており, 判然としない. また, 対応する シズルワード「おしゃれな」との結びつきが単語の傾向のみか らは判断しがたい. その一方で, 第 14 因子は他の因子とは 類似していないものの,「トースター」「ベーグル」「クッキー」 「バター」「クリーム」などといった，パンに代表される小麦粉を 用いた料理を連想させるキーワードが多く含まれており，これら は，シズルワード「あつあつ」「あたたか」「カリカリ」などの 調理内容をイメージしやすいキーワードが多く含まれている.

第 14 因子と第 1 因子を比較すると, 第 14 因子はパンなどを ベースとしたメニューであることから，一般的な料理レシピ とは異なり, 因子が独立していたと考えられる，その一方で, 第 1 因子は, 複数の要因が混在してしまい, 内容の解釈が難し くなったため類似した因子が存在しなかったと考えられる.

上記の様に, NMFの因子（トピック）における単語の重み に注目することで, シズルワードの内容に関する解釈が可能 になる，シズルワードは感覚的な表現であり, 同様な印象を 受ける複数のシズルワードから構成される食における感性の
表現に関する共通性を抽出できたと考えている.ささらに, その因子に対応する関連単語の因子に着目することで，その シズル感が, どのような文脈で利用されているのかが把握で きた。ここでは，因子として抽出されたそれぞれのシズル感 に対して, 影響を及ぼす食材や調味料, それらの利用場面, 用途などの具体的な情報が抽出できた．

これらの性質を通じて, 同様な表現でも内容や利用する 意図が異なることが確認できた。たとえば，「あたたか」と 「アツアツ」のように食品の温度が高い様子を表すシズルワー ドであっても，NMFの解析では異なるトピックを形成してお り, 用途や利用対象が全く異なるものであった。本研究の アプローチによってこのような微妙な差異が利用時における 用途や文脈の差異に影響を及ぼすことが確認できた。これよ り, 我々のアプローチが, 印象の把握が容易ではないシズル感 に関する情報の理解支援ツールとして機能すると考えている.

\section{6. まとめと今後の課題}

\section{1 まとめ}

本研究では，シズルワードに関する因子情報の抽出を目的 とし，言語資源において NMFを適用することで解析を行っ た，NMFの特徵量には，シズルワードを含むレシピサイト のレビュー文を対象として解析を行った. その際, シズルワー ド間の利用頻度の差異を緩和するためにBM25による単語 の重み付けを施すことで, 解析の精度向上を試みた。学習結 果に対して，ワードクラウド拈よびそれらの関係性をネット ワークとして表示することで，シズルワードの性質に関する 情報を可視化し，解釈を与えた。

シズルワードは食において製品内容に関するイメージや情 報を端的に顧客に伝える際に有効である。 パッケージや広告 において, 顧客が抱くイメージと実際の製品の間に齟齬があ ると, 顧客満足度の低下につながりやすいことから，このよ うなシズルワードの理解は食のマーケティングにおいて重要 である。昨今におけるデー夕解析環境の発展は目覚ましいこ とからも，シズルワードなどに代表される感性的な表現に対 する知見の獲得は今後ますます進展すると考えている。

\section{2 今後の課題}

NMFの学習結果においては, 因子に対して何らかの解釈を 与えた際にその内容にそぐわないキーワードも含まれていた。 このような単語はノイズであり，このような単語が含まれな いような前処理方法の構築が今後重要になると考えられる. また，今回対象としたデータはレシピサイトにおけるレポー トのコメントであり, 対象はレシピに限定されたものであっ たため, 家庭で作られる食品が中心であった。このため, 市中に㧍ける商品や飲食店で提供されるメニューを対象とし た表現はほとんど含まれていなかった。したがって，データ をTwitterなどのマイクロブログや他のカスタマーレビューの データを対象として対象メディアに㧍ける利用傾向の差異が 学習結果に及ぼす影響について検討する必要があるといえる. 
さらに，本研究では分析対象のデータを食におけるコメン トに限定したことから, 対象表現 (シズルワード)の多義性 については考慮されていない，たとえば,「なめらか」や 「さらさら」などは食べ物以外の様々な対象にも広く用いら れる表現であることから, 文脈において用途や意味あいが 大きく異なる，今後は，このようなコメントデー夕の対象範 囲が広がった際における文脈や対象を考慮した解析も重要に なると考えている

また，シズルワードの内容に着目すると，「おしゃれな」 「お酒落な」や「あっさり」「アッサリ」のように, 表現にて 利用する文字は異なるが同意な内容が共通因子に含まれてい た。これより，NMFの学習結果においても意味的に同義な 語を分別できていることが確認できたが，その一方で，ここ に扔ける重みの強弱は, 利用する文字の違いから何らかの影 響を受けているといえる. カタカナ・ひらがな・漢字の利用 によって書き手・読み手の印象が異なることは容易に想像で きることから，この差異が印象や用途に及ぼす影響を調査・ 検討することは今後さらに重要になると思われる。このよう な差異の検出においては先行研究で用いられてきたルール ベースの解析が有効であると考えている.

利用した解析手法に目を向けると, 近年では, 言語資源か ら概念的な情報を抽出するにあたり要素技術の発展は目覚ま しいことから, 他の学習モデルの利用も検討する必要があ る. Word2 vecや深層学習などのニューラルネットに基づい た方法によって高い性能が示されていることから，今後はこ れらの方法の適用について検討していきたい.

\section{謝 辞}

分析用のデータセットを提供して頂きました, 楽天株式会社様 に，この場を扮借りして厚く御礼申し上げます。

\section{注}

[注 1] 楽天レシピ<https://recipe.rakuten.co.jp/ >

[注2］削除した単語の例として「ごちそうさま」「コンニチハ」

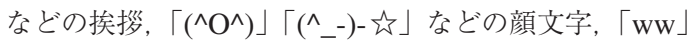

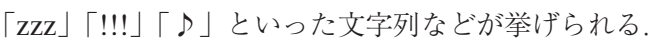

\section{参 考 文 献}

[1] 大橋正房, 光岡祐子, 須藤正彦, 北村奈津子, 米山真知子, 猿渡一兵 : sizzle word シズルワードの現在「おいしいを 感じる言葉」調査報, B·M·FT出版部, 2015 .

［2］石橋賢, 深瀧創, 宮田一乘 : 米菓を対象としたシズル語の 印象評価, 人工知能学会論文誌, 30(1), pp.229-236, 2015.

[3] 高橋康介, 三橋秀男, 村田一仁, 則枝真, 渡邊克巳 : 対人 接触行動の感性情報とその因子空間, 感性工学会論文誌, 10(2), pp.261-268, 2011

４4］矢口幸康：オノマトペをもちいた共感覚的表現の意味理解 構造, 認知心理学研究, 8(2), pp.119-129, 2011.
［5］山本裕子，佐藤弘喜：オノマトペを用いたイメージ共有に 関する研究, 日本デザイン学会第 62 回研究発表大会概要 集, A3-3, 2015 .

[6] 加藤大介, 宮部真衣, 若宮翔子, 荒牧英治, 瀧本明代 : 類似するシズル感を持つ食品検索手法の提案，第14 回日 本データベース学会年次大会, E2-6, 2016.

[7] ラートサムルアイパン・カンウイッパー, 渡辺知恵美, 中村聡史：オノマトペロリーオノマトペを利用した料理推 薦システムー, 情報処理学会研究報告, DD-73(6), pp.1-7, 2009.

［8］青木光, 齊藤史哲, 石津昌平：感性表現に基づいたクチコ ミ情報からの顧客満足度に関する知識抽出, 平成 27 年度 経営工学会春季大会予稿集, pp.130-131，2014.

[9] Lee, D.D., Seung, H.S.: Learning the parts of objects by non-negative matrix factorization, Nature, 401(6755), pp.788-791, 1999.

[10] Lee, D. D., Seung, H. S.: Algorithms for Non-negative Matrix Factorization, Proc. of Conference on Neural Information Processing Systems (NIPS), 13, pp.556-562, 2000.

[11] 安川武彦：非負值行列因子分解を用いたテキストデー夕解 析, 計算機統計学, 28(1), pp.41-55, 2015.

[12］幸島匡宏, 松林達史, 澤田宏: 属性情報を考慮した消費者 行動パターン抽出のための非負值多重行列因子分解法, 人工知能学会論文誌, 30(6), pp.745-754, 2015.

[13] 橋本泰一, 村上浩司, 乾孝司, 内海和夫, 石川正道: 社会 課題発見のための文書クラスタリングとクラスタ評価指標, 人工知能学会論文誌, 24(4), pp.333-338, 2009.

[14] Buettcher, S., Clarke, C.L. A., Cormack, G. V.: Information Retrieval: Implementing and Evaluating Search Engines, MIT Press, 2016

[15］奥村秀人, 徳久雅人, 村上仁一, 村田真樹：観光地に対卞 る長所情報の収集と分類の試み, 信学技報 (思考と言語), 110 (244), pp.25-30, 2010.

[16] 森田真季, 荒牧英治, 灘本明代, 宮部真衣 : マイクロブロ グにおける“おいしさ”情報分類器の適用可能性の検証, 信学技報 (LOIS), 116(488), pp.229-234, 2017 .

[17] 加藤大介, 宮部真衣, 荒牧英治, 灘本明代: Twitter, Web, レシピサイトに打けるおいしさ表現の比較分析, 信学技報（デー夕工学），114(204), pp.19-24, 2014

[18］都甲潔：感性バイオセンサ, 経営システム, 26(1), pp.32-36, 2016.

[19］瀬戸賢一(編著)：ことばは味を超える，海鳴社， 2003.

[20] B·M·TFことばラボ：ふわとろ, B · M $\mathrm{TF}$ 出版部, 2016.

[21］高垣敦郎：「拈いしい」のマーケティングリサーチ, 碩学舎, 2015 .

[22］川端晶子, 淵上匠子(編著)：おいしさの表現辞典, 東京堂 出版, 2006.

[23］伏木亨：人間は脳で食べている, ちくま新書, 2005. 


\section{長谷川 永奈 (非会員)}

2017 年 青山学院大学理工学部経営システム工学科卒業. 在学中 はシズルワードの解析に関する研究に従事.

小宮 香乃 (非会員)

2017 年 青山学院大学理工学部経営システム工学科卒業. 在学中 は文書データの分析に関する研究に従事.

齊藤 史哲 (正会員)

2009 年 東京工業大学大学院総合理工学研究科知能システム科学 専攻博士後期課程修了. 博士 (工学). 同年, 同大学精密工学研 究所研究員等を経て, 2011 年青山学院大学理工学部経営システ ム工学科助手, 2013 年より同助教, 現在に至る. 主として, システム工学・経営工学分野における知的情報処理（機械学習· エージェントモデルなど）に関する研究に従事. 人工知能学会, 電気学会, 知能情報ファジィ学会, 日本経営工学会, 電子情報 通信学会, IEEE等会員.

\section{石津 昌平 (正会員)}

1980 年 広島大学大学院工学研究科博士後期課程修了. 青山学院 大学理工学部経営システム工学科教授. 工学博士. システム評価 理論, 品質経営システム, 品質管理のための分析技術, ラフ集合 理論, 感性工学に関する研究に従事. 日本品質管理学会, 日本 経営工学会, 計測自動制御学会, 日本経営情報学会各会員. 